Jurnal Kejaora: Jurnal Kesehatan Jasmani dan Olah Raga

ISSN: 2541-5042 (Online)

ISSN: 2503-2976 (Print)

Volume 5 Nomor 1, Edisi April 2020

\title{
UPAYA MENINGKATKAN HASIL BELAJAR BERMAIN BOLABASKET MELALUI PENERAPAN PENDEKATAN TAKTIS PADA PESERTA DIDIK SMA DI SUKOHARJO
}

\author{
Ahmad Septiandika Adirahma \\ Prodi Pendidikan Jasmani, Kesehatan dan Rekreasi FKOR UNS \\ Email: andiktreze@staff.uns.ac.id \\ DOI: https://doi.org/10.36526/kejaora.v5i1.839
}

\begin{abstract}
ABSTRAK
Penelitian ini merupakan Penelitian Tindakan Kelas (classroom action research) yang bertujuan untuk meningkatkan hasil belajar bermain bolabasket. Subjek dalam Penelitian ini adalah peserta didik kelas XI IPA 1 SMA Negeri 1 Sukoharjo yang berjumlah 29 peserta didik. Penelitian ini menggunakan teknik analisis deskriptif kuantitatif dengan menggunakan teknik persentase untuk melihat kecenderungan yang terjadi dalam kegiatan pembelajaran. Penelitian ini diselesaikan dalam siklus 2 ketuntasan belajar mencapai $86,21 \%$ dengan KKM 75, adapun target capaian ketuntasan yang ditetapkan oleh peneliti adalah $80 \%$. Terbukti berdasarkan hasil analisis data diatas dapat disimpulkan bahwa: penerapan pendekatan taktis dapat meningkatkan hasil belajar bermain bolabasket pada peserta didik kelas XI IPA 1 SMA Negeri 1 Sukoharjo Tahun Pelajaran 2019/2020.
\end{abstract}

Kata Kunci: Hasil Belajar, Pendekatan Taktis, Bermain Bolabasket

\section{PENDAHULUAN}

Dalam upaya memberikan kebebasan mengembangkan kreatifitas peserta didik dalam mengikuti aktifitas pembelajaran pendidikan jasmani utamanya bermain bolabasket, seorang guru pendidikan jasmani bisa menggunakan metode, model dan gaya mengajar yang sesuai, yang dapat diaplikasikan ke dalam pembelajaran agar semua potensi dari setiap peserta didik dapat berkembang. Selain itu guru, juga harus menguasai model, metode, dan gaya mengajar yang dipilih dalam memberikan suatu materi pembelajaran, karena hal ini juga akan menentukan akan efektif atau tidaknya dari suatu model, metode atau gaya mengajar yang dipilih tersebut terhadap hasil belajar yang akan diperoleh peserta didik dalam mengikuti kegiatan pembelajaran.

Pendekatan pembelajaran melalui pendekatan taktis dapat menjadi pilihan, dimana peserta didik akan diperkenalkan pada konsep dan nilai - nilai mata pelajaran PJOK kaitannya dengan olahraga permainan, kemudian peserta didik akan memahami serta mengerti kegunaan praktisnya. Karena pada pendekatan taktis berusaha menghubungkan kemampuan bermain dan keterampilan teknik dasar dengan menekankan pemilihan waktu yang tepat untuk melatih teknik dasar dan aplikasi dari pada teknik dasar tersebut kedalam keterkaitannya pada kemampuan taktis bermain, kemudian akan mampu merangsang peserta didik untuk berfikir dan menemukan sendiri alasan-alasan yang melandasi gerak dan penampilannya (performance). Sehingga diharapkan dari kebiasaan yang telah dilakukan akan memberikan peningkatan juga yang dapat diukur sesuai dengan instrumen penilaian dari aspek kognitif, afektif dan psikomotor. Menurut Tomoliyus (2001), menyebutkan bahwa, "Dalam pendidikan jasmani dikenal dua pendekatan dalam pembelajaran, yaitu pendekatan teknik (pengajaran tertutup) dan pendekatan keterampilan taktik (pengajaran terbuka)."

Berdasarkan hasil observasi pada peserta didik kelas XI IPA 1 SMA Negeri 1 Sukoharjo terdapat permasalahan yaitu peserta didik cenderung kurang bersemangat pada saat mengikuti pembelajaran PJOK materi bermain bolabasket. Kemudian peneliti mencari informasi lebih lanjut kepada peserta didik berkaitan dengan hal tersebut, dan didapat alasan bahwa pembelajaran yang diberikan banyak berpusat pada guru artinya 
Jurnal Kejaora: Jurnal Kesehatan Jasmani dan Olah Raga

ISSN: 2541-5042 (Online)

ISSN: 2503-2976 (Print)

Volume 5 Nomor 1, Edisi April 2020

guru hanya sebatas memberikan teori - teori tentang materi yang diajarkan. Hal ini yang menjadikan proses pembelajaran terasa membosankan, sehingga berdampak pada motivasi peserta didik mengikuti pembelajaran PJOK berkurang. Disisi lain ketika pembelajaran memasuki materi permainan, peserta didik ingin langsung melakukan permainan, meskipun sebagian peserta didik kurang menguasai keterampilan dalam bermain bolabasket. Hal ini yang membuat peserta didik terkendala dengan adanya aturan-aturan yang diterapkan dalam permainan bolabasket. Sehingga dari masalah - masalah tersebut berdampak pada pencapaian hasil belajar yang kurang maksimal. Menurut Griffin \& Butler (2005), "Pembelajaran pendekatan taktis adalah sebuah pendekatan yang berpusat pada peserta didik dan permainan untuk pembelajaran permainan yang berkaitan dengan olahraga yang kuat hubungannya dengan pendekatan kontruktivisme pada pembelajaran".

Pendekatan taktik dalam pembelajaran berusaha mengajarkan peserta didik dalam hal keterampilan. Keterampilan yang dimaksud adalah teknik cabang olahraga bolabasket dan sekaligus mengajarkan penerapan dalam situasi permainan bolabasket. Sehingga pendekatan ini memiliki penekanan pada bermain, dimana peserta didik akan mendapat pemahaman yang lebih baik tentang situasi permainan olahraga yang sesungguhnya, yang memerlukan keterampilan taktik untuk mengambil keputusan dalam situasi permainan namun tidak mengesampingkan dari pentingnya keterampilan teknik. Mitchell, Oslin ,\& Griffin (2003) menerangkan bahwa Pendekatan Taktis membedakan permainan dalam 4 kelompok bentuk permainan, yaitu: (1) Target games (Permainan Target), 2) Net/Wall games (Permainan Net), (3) Striking/ fielding games (Permainan pukul-tangkaplari), (4) Invasion games (Permaian Serangan/invasi)

Dalam memberikan materi, seorang pendidik harus dapat mengarahkan peserta didik untuk dapat melatih berfikir kritis menggunakan kognisinya guna memecahkan permasalahan taktik yang ada dalam

permainan. Tujuannya agar peserta didik tidak gagap ketika mentransfer keterampilan teknik yang dikuasai dalam situasi permainan. Sehingga penerapan pendekatan taktis dalam pembelajaran dirasa cukup mampu membantu peserta didik dalam membangun pemikiran bermainnya.

Dalam penerapan pendekatan pembelajaran cenderung masih banyak yang menggunakan teacher centered artinya pembelajaran masih banyak didominasi oleh guru, utamanya dalam cabang olahraga permainan dipandang kurang efektif untuk meningkatkan keterampilan dalam bermain, karena peserta didik hanya sebatas mendengarkan apa yang disampaikan oleh guru, kemudian dalam aplikasinya dilapangan guru kurang memperhatikan hal - hal apa saja yang dilakukan oleh peserta didik terutama kesalahan yang dialami, sehingga peserta didik terkendala pada peraturan peraturan yang diterapkan dalam permainan tersebut. Gejala ini tampak jelas pada saat pembelajaran bolabasket. Peserta didik cenderung akan cepat merasa bosan dan jenuh ketika berlatih unsur teknik, karena guru hanya sebatas mengarahkan pada latihan secara berulang - ulang dan sifatnya monoton.

\section{Konsep Pembelajaran Bolabasket melalui Pendekatan Taktis}

Permainan bolabasket, merupakan olahraga yang didalamnya terdapat gerakangerakan yang kompleks dalam melakukan permainan, mulai dari kecepatan kaki dan tangan, kesigapan gerakan seluruh tubuh serta efisiensi penggunaan waktu yang tepat untuk menentukan suatu gerakan secara tepat dan cepat. Kemudian untuk membawa peserta didik ke dalam situasi permainan yang sebenarnya maka perlu adanya modifikasi permainan atau yang telah disesuaikan dengan permainan aslinya. Sehingga akan membuat peserta didik lebih cepat dan lebih mudah dalam menerima pembelajaran yang diberikan. Adapun beberapa permainan yang akan peneliti gunakan dan diterapkan untuk pelajaran PJOKorkes dalam pembelajaran bolabasket antara lain: 
Jurnal Kejaora: Jurnal Kesehatan Jasmani dan Olah Raga

ISSN: 2541-5042 (Online)

ISSN: 2503-2976 (Print)

Volume 5 Nomor 1, Edisi April 2020

\section{a. Permainan Defense}

1) Tujuan:

Pada permainan ini peserta didik diharapkan dapat belajar melatih kemampuan berfikirnya dalam situasi permainan untuk mengaplikasikan teknik gerak tipu tanpa bola, kemudian peserta didik juga belajar melakukan pertahanan daerah atau zone deffense dan penyerangan terhadap zone deffense.

2) Manfaat:

Dalam permainan ini menekankan pada bagian teknik dasar bergerak tanpa bola, sehingga secara tidak langsung peserta didik akan dihadapkan pada dua permasalahan taktis dalam permainan, yakni pertahanan dan penyerangan tanpa menggunakan bola dalam prinsipnya untuk mencari tempat yang kosong guna mensupport kawan ketika bermain.

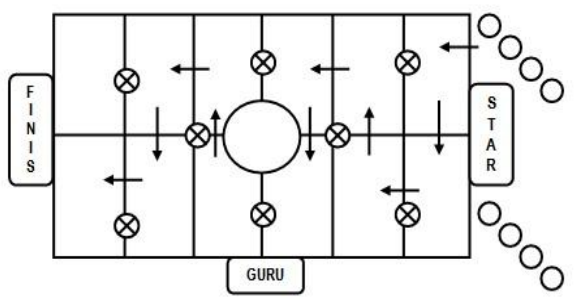

Gambar 1. Permainan Defense

3) Cara memainkan:

Peserta didik akan dibagi menjadi dua kelompok besar, dalam permainan akan yang kemudian akan ada tim bertahan dan penyerang. Pada tim bertahan peserta didik melakukan pertahanan daerahnya, sedangkan untuk tim penyerang peserta didik diharuskan untuk melewati daerah per daerah untuk mencari tempat kosong dan utamanya menghindar dari pemain bertahan untuk menuju ke zona aman. Ketika pemain penyerang terkena oleh pemain bertahan maka dia akn dinyatakan gugur. Permainan berakhir ketika jumlah pemain penyerang adalah setengah dari keseluruhan jumlah pemain di tim tersebut.

\section{b. Permainan Passing dan Steal}

1) Tujuan:

Peserta didik mampu belajar berfikir cepat dalam situasi permainan yang sempit utamanya berlatih posisi triangle dalam melakukan operan.

2) Manfaat:

Dalam permainan ini menekankan pada kemampuan berfikir.Dimana peserta didik akan mengetahui bagaimana cara melakukan operan dan tangkapan secara tepat dan akurat.

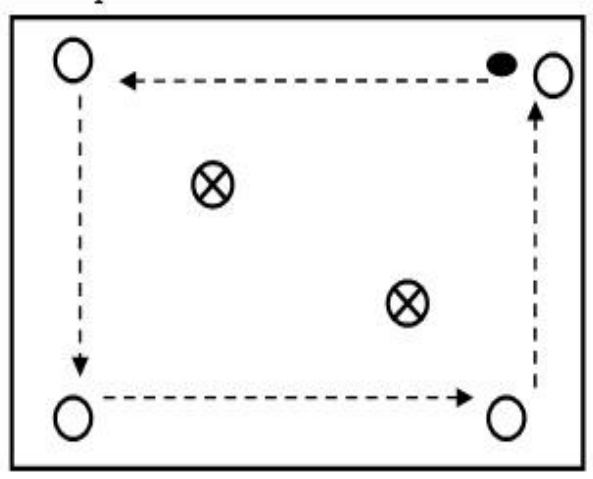

Gambar 2. Permainan Passing dan Steal

3) Cara memainkan:

Pertama akan dibuat area berbentuk kotak berukuran $4 \times 4$ meter yang diberi tanda menggunakan cone atau bilah. Dimana setiap kotak nantinya akan berisi lima peserta didik. Kemudian akan ada dua peserta didik yang bertugas sebagai pemain bertahan dan berusaha merebut bola dengan cara menutup arah atau lintasan operan bola, sedangkan tiga peserta didik yang lainnya berada di tiga sudut yang berbeda di kotak tersebut. Melakukan teknik operan dan berpindah tempat namun masih di dalam area kotak tersebut. Atau yang disebut dengan triangle position.

\section{c. Permainan Passing}

1) Tujuan:

Peserta didik belajar mengaplikasikan teknik bergerak tanpa bola dan operan serta kesalahan travelling utamanya dalam situasi bermain. Kemudian penggunaan strategi bermain yang tepat dalam upanya melakukan penyerangan ke daerah pertahanan lawan dan untuk mendapatkan angka.

2) Manfaat:

Pada permainan ini menggunakan kombinasi pergerakan dengan bola dan tanpa bola untuk menguasai bola dan mendukung 
Jurnal Kejaora: Jurnal Kesehatan Jasmani dan Olah Raga

ISSN: 2541-5042 (Online)

ISSN: 2503-2976 (Print)

Volume 5 Nomor 1, Edisi April 2020

pergerakan teman, juga untuk menciptakan jalur - jalur operan serta penerapan strategi yang tepat dalam bermain. Sehingga peserta didik akan belajar prinsip bagaimana cara mencetak poin dalam permainan bolabasket melalui kerjasama tim.

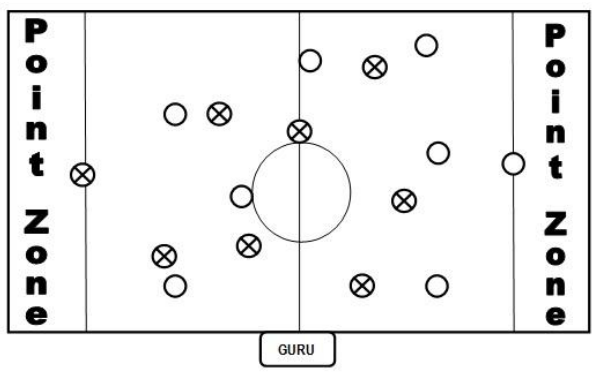

Gambar 3. Permainan Passing

\section{3) Cara Memainkan:}

Peserta didik akan dibagi menjadi beberapa kelompok kecil. Masing-masing kelompok berisikan 7-8 peserta didik. Setiap kelompok harus memiliki satu orang yang bertugas menjadi penjaga daerah poin. Ketika akan mencetak poin, semua pemain boleh melakukan pergerakan kemana saja untuk mendapatkan bola kaitannya untuk menciptakan jalur operan, dan kemudian boleh mengoper bola ke teman yang lainnya. Kemudian menuju ke daerah poin untuk mencetak angka, tim yang berhasil membawa bola ke daerah poin maka akan mendapat dua angka. Permainan akan berlangsung selama 7 menit setiap pertandingan.

\section{4) Aturan:}

Pemain tidak boleh melakukan dribble. Pemain tidak boleh berlari atau berjalan lebih dari dua langkah ketika memegang bola. Hanya boleh melakukan pivot untuk mencari rekan setimnya.

\section{d. Permainan Offense}

1) Tujuan:

Peserta didik dapat memahami apa yang harus dilakukan sesuai posisinya atau tugas yang harus dilakukannya dan membiasakan teknik dan hal selanjutnya yang harus dilakukan. Kemudian untuk mengusahakan bola masuk dari setiap tembakan yang dilakukan kaitannya untuk mendapat point.
2) Manfaat:

Dalam permainan ini menekankan pada akurasi melakukan passing panjang dengan menggunakan overhead pass, kemudian juga peserta didik akan belajar refleks ketika mendapat bola kemudian bagaimana mengendalikan bola pada situasi yang tidak biasa seperti melewati rintangan.

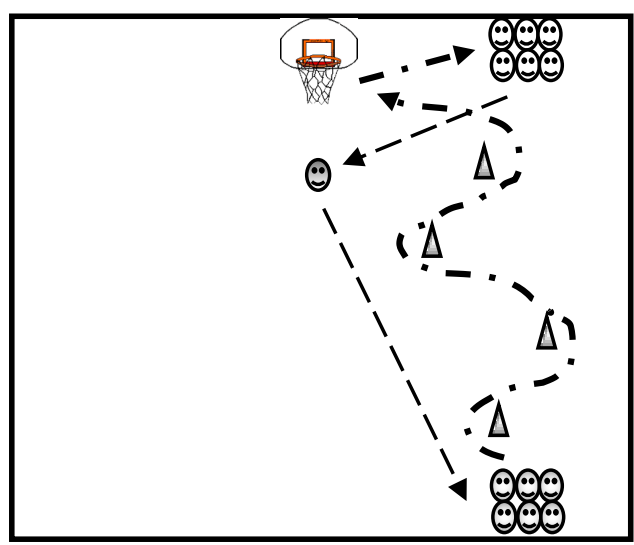

Gambar 4.Permainan Offense

3) Cara memainkan:

Pertama peserta didik akan dibentuk menjadi dua tim besar. Permainan akan dilakukan secara kompetisi antar tim yang satu dengan yang lainnya. Pertama, dalam masing-masing tim akan dibagi menjadi dua posisi, yakni peserta didik yang melakukan operan dan peserta didik yang melakukan dribble bola. Tugas dari masing - masing posisi adalah pada titik operan, peserta didik melakukan operan dari atas kepala ke teman se timnya, kemudian peserta didik yang berada dititik dribble, setelah mendapatkan bola maka harus menggiring bola melewati cone yang sudah disusun secara zig-zag kemudian melakukan finishing dengan lay up kanan apabila masuk akan mendapatkan poin dua angka. Selanjutnya, peserta didik yang telah melakukan operan maka harus berada di titik rebound kemudian mengembalikan bola ke temannya di titik operan dan berlari ke titik melakukan dribble dan yang telah melakukan dribble menuju ke titik operan atau dapat dikatakan change position. Begitu seterusnya hingga salah satu dari tim tersebut mendapat point sebanyak 20, sehingga dikatakan menang. Dan tim yang kalah mendapat hukuman. 
Jurnal Kejaora: Jurnal Kesehatan Jasmani dan Olah Raga

ISSN: 2541-5042 (Online)

ISSN: 2503-2976 (Print)

Volume 5 Nomor 1, Edisi April 2020

\section{e. Permainan 5 on 5}

1) Tujuan:

Peserta didik belajar pada penerapan seluruh teknik dalam permainan bolabasket dalam pertandingan yang sebenarnya secara tepat dan efisien.

\section{2) Manfaat:}

Peserta didik akan lebih memahami tugasnya dan apa yang harus dilakukan tanpa bola dan dengan menggunakan bola.

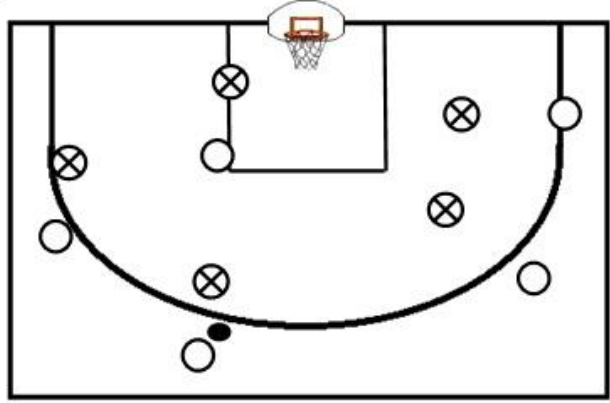

Gambar 5. Permainan 5 on 5

3) Cara memainkan:

Sesuai dengan permainan bolabasket, peserta didik boleh mengaplikasikan semua teknik bermain bolabasket dalam permainan utamanya untuk mencetak point. Namun dalam permainan ini hanya akan menggunakan setengah lapangan dari keseluruhan lapangan yang digunakan dalam pertandingan bolabasket. Peserta didik boleh menggiring, mengoper, menembak, melakukan pivot dan lain sebagainya untuk membuat timnya menang. Perminan akan dibatasi waktu yakni selama $2 \times 3$ menit untuk setiap pertandingan.

\section{METODE}

Penelitian ini merupakan penelitian tindakan kelas. Menurut Kristiyanto (2010) Ada 4 langkah pokok PTK pada setiap siklusnya, meliputi: (1) perencanaan tindakan, (2) pelaksanaan tindakan, (3) observasi, dan (4) Refleksi". Teknik pengumpulan data yang digunakan peneliti adalah observasi ketika peserta didik pada saat pembelajaran bolabasket melalui penerapan pendekatan taktis. Uji validitas data penelliti menggunakan teknik penilaian triangulasi data. Analisis data menggunakan teknik analisis deskriptif kuantitatif dengan

menggunakan teknik persentase untuk melihat kecenderungan yang terjadi dalam kegiatan pembelajaran. Aspek Psikomotor peneliti menggunakan instrumen Game Performance Assessment Instrument (GPAl) (Griffin, Mitchell dan Oslin. 2013)

\section{HASIL DAN PEMBAHASAN}

Dengan menerapkan Pendekatan Taktis dapat mempengaruhi peningkatan kemampuan dan keterampilan peserta didik dalam bermain bolabasket, disisi lain penggunaan Pendekatan Taktis untuk pembelajaran permainan bolabasket juga berpengaruh terhadap hasil belajar peserta didik untuk materi permainan bolabasket berupa unjuk kerja, pemahaman gerakan dan sikap peserta didik selama melakukan dan mengikuti kegiatan belajar mengajar pada siklus I dan siklus II.

Kondisi awal peserta didik belum menunjukkan hasil yang maksimal dalam materi bermain bolabasket. Pembelajaran bermain bolabasket di SMA Negeri 1 Sukoharjo sudah berjalan sesuai dengan rncana pelaksanaan pembelajaran yang telah dibuat oleh guru namun peserta didik belum mampu menguasai keterampilan bermain bolabasket dengan baik dan benar. Pada pra-siklus hasil belajar bermain bolabasket pada kategori cukup sebesar $24,14 \%$ atau sebanyak 7 peserta didik, kurang sebesar $72,41 \%$ atau sebanyak 21 peserta didik dan kurang sekali sebesar $3,45 \%$ atau sebanyak 1 peserta didik dengan 7 peserta didik yang masuk kriteria tuntas dan 22 peserta didik tidak tuntas. Pada siklus I hasil belajar bermain bolabasket pada kategori Cukup sebesar $62,07 \%$ atau sebanyak 18 peserta didik, dan Kurang sebesar $37,93 \%$ atau sebanyak 11 peserta didik dengan 18 peserta didik yang masuk pada kriteria tuntas dan 11 peserta didik tidak tuntas. Sedangkan pada siklus II hasil belajar bermain bolabasket pada kategori Baik sebesar $17,24 \%$ atau sebanyak 5 peserta didik, Cukup sebesar $68,97 \%$ atau sebanyak 20 peserta didik, dan Kurang sebesar $13,79 \%$ atau sebanyak 4 peserta didik dengan 25 peserta didik mencapai kriteria tuntas dan 4 peserta didik tidak tuntas. 
Jurnal Kejaora: Jurnal Kesehatan Jasmani dan Olah Raga

ISSN: 2541-5042 (Online)

ISSN: 2503-2976 (Print)

Volume 5 Nomor 1, Edisi April 2020

Tabel 1.Capaian Hasil Belajar Bermain Bermain

Bolabasket Setelah Menggunakan Pendekatan Taktis.

\begin{tabular}{|c|c|c|c|c|}
\hline \multirow{2}{*}{$\begin{array}{c}\text { Aspek } \\
\text { yang } \\
\text { diukur }\end{array}$} & \multicolumn{3}{|c|}{ Persentase } & \multirow{2}{*}{ 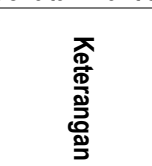 } \\
\hline & 胥 & $-\frac{\infty}{\frac{\infty}{\bar{i}}}$ & $=\frac{\infty}{\overline{\bar{i}}}$ & \\
\hline $\begin{array}{l}\text { Keterampil } \\
\text { an } \\
\text { Bermain } \\
\text { Bolabaske } \\
\text { t. }\end{array}$ & $\begin{array}{l}24,14 \\
\%\end{array}$ & $\begin{array}{l}62,07 \\
\%\end{array}$ & $\begin{array}{l}86,21 \\
\%\end{array}$ & $\begin{array}{l}\text { Lembar } \\
\text { peilaian } \\
\text { menggunaka } \\
\text { n GPAl atau } \\
\text { IPPB dengan } \\
\text { disesuaikanK } \\
\text { KM sekolah } \\
\text { sebesar } 75 \text {. }\end{array}$ \\
\hline
\end{tabular}

Peningkatan terjadi pada siklus I dan siklus II setelah peserta didik mendapat tindakan yakni pembelajaran bermain bolabasket dengan menggunakan penerapan pendekatan taktis. Hasil belajar bermain bolabasket pada siklus I mengalami peningkatan walaupun belum optimal. Pelaksanaan siklus II yang berfokus pada penguatan materi yang belum dapat dikuasai peserta didik secara maksimal, pada akhirnya dapat meningkatkan hasil belajar bermain bolabasket menjadi lebih baik. Proses pembelajaran yang tercipta juga lebih efektif dan efisien karena peserta didik lebih aktif dalam proses pembelajaran sehingga suasana yang tercipta semakin menyenangkan dan membantu menciptakan proses kegiatan belajar mengajar yang berkualitas.

Penelitian pada peserta didik kelas XI IPA 1 SMA Negeri 1 Sukoharjo tahun pelajaran 2019/2020 dilaksanakan dalam dua siklus. Pada kondisi sebelum diberikan tindakan peserta didik yang masuk dalam kriteria tuntas sebesar $24,14 \%$ atau 7 peserta didik. Pada siklus I, ketuntasan belajar bermain bola basket peserta didik adalah 18 peserta didik atau sebesar $62,07 \%$ dari jumlah keseluruhan 29 peserta didik. Pada siklus II, ketuntasan belajar bermain bola basket peserta didik adalah 25 peserta didik atau sebesar $86,21 \%$ dari jumlah keseluruhan 29 peserta didik, dengan KKM 75. Sudah melewati target capaian peneliti sebesar 80 $\%$.

Penelitian ini memberikan suatu gambaran yang jelas bahwa keberhasilan proses pembelajaran tergantung beberapa faktor yang dapat mempengaruhinya. Faktor- faktor tersebut dapat berasal dari guru maupun peserta didik secara garis besar. Artinya ketika faktor berasal dari guru, ditekankan pada kemampuan guru tersebut dalam bagaimana cara mengelola kelas dan mengembangkan materi yang diberikannya mengenai cara menyampaikan, metode pembelajaran yang digunakan, ataupun pendekatan yang dilakukan dalam proses pembelajaran sebagai sarana dalam usaha menyampaikan materi secara maksimal kepada peserta didik. Sedangkan faktor dari peserta didik, adalah mengenai bagaimana peserta didik tersebut antusias terhadap pembelajaran sehingga dari situ dapat dijadikan tolok ukur motivasi peserta didik dalam mengikuti proses kegiatan belajar mengajar.

\section{KESIMPULAN}

Penelitian ini juga memberikan deskripsi secara jelas bahwa dengan menerapkan pendekatan taktis dalam proses pembelajaran bermain permainan bolabasket, dapat meningkatkan hasil belajar peserta didik (baik secara proses maupun hasil), sehingga penelitian ini dapat digunakan sebagai bahan pertimbangan bagi guru PJOK untuk melaksanan kegiatan belajar mengajar menggunakan penerapan pendekatan taktis. Karena pada dasarnya tidak semua peserta didik dalam lingkup sekolah menyukai olahraga bolabasket, dan disisi lain dapat mengubah persepsi peserta didik pada pembelajaran olahraga yang melelahkan dan membosankan dengan materi dan pembelajaran yang diberikan hanya mengenai materi itu-itu saja.

\section{DAFTAR PUSTAKA}

Kristiyanto, A. (2010). Penelitian Tindakan Kelas (PTK) Dalam Pendidikan Jasmani Dan Kepelatihan Olahraga. Surakarta: Uns Press

Griffin \& Butler, J. (2005). Teaching Games for Understanding: Theory, research, and practice. Windsor: Human Kinetics.

Mitchell, S.A., Oslin, J., dan Griffin, L. (2003). Sport Foundation for Elementary Physical Education: A Tactical Games 
Jurnal Kejaora: Jurnal Kesehatan Jasmani dan Olah Raga

ISSN: 2541-5042 (Online)

ISSN: 2503-2976 (Print)

Volume 5 Nomor 1, Edisi April 2020

Appoach. Champaign: Human

Kinetics

Mitchel, Oslin, \& Griffin. (2013). Teaching Sport Concept and Skills. Canada. Human Kinetics.

Tomoliyus. (2001). Pendekatan Keterampilan Taktis dalam Pembelajaran Bola Basket. Jakarta: Dirjen Olahraga, Depdiknas. 